\title{
Comparison between South Korea and Turkey's High School History Curriculums in terms of Teaching-Learning
}

\author{
Ee Young Cho ${ }^{1} \quad$ Chong Woo $\mathrm{Cho}^{2}$
}

\begin{abstract}
In this study, it is to compare between South Korea and Turkey's high school class history programs in terms of learning- teaching. The South Korea's high school programs as well as Turkey's high school programs were found via internet. The aim, the content, and the learning and teaching of South Korea and Turkey's high school history programs are discussed as well as the evaluation of measurement of its situation and which purpose the education has been given has been discussed. In the study, the comparison between Korean history lesson and Turkey's $9^{\text {th }}$ grade history lesson, between Korean East Asia history and Turkey's $10^{\text {th }}$ grade history lesson, and between Korean world history lesson and contemporary Turkey's history and world history lesson has been done. It is to attempt to see Korea and Turkey's high school student's history programs learning- teaching by comparing two countries' similarities and differences. Program for history of Korea and program for history of Turkey have been solved through document analysis technique and the descriptive analysis technique. In regards to two countries learning-teaching situations, historical thinking skills, raising awareness, active participation of students and motivating students, student using historical locations, raising imagination and creativity, and using visual means has been targeted as goals. Regarding the differences, it has shown that Korea had more variety of differences of teaching-learning than Turkey and the usage of technology system in teaching in Korea has been widespread than in Turkey. Also, the importance of female and male contribution concerning the subject of history has been given importance in Turkey. The importance of critical thinking of the students has been emphasized in Korea.
\end{abstract}

Key Words: High School, History Curriculum, Learning-Teaching, Historical thinking skills

\section{INTRODUCTION}

During the education process, it is important to provide each student with various knowledge, skills, attitudes, mental development and most importantly personal development. Atay (1996) mentioned that providing students' needs are essential in developing areas of education programs which include assisting students to develop physically, cognitively, social-emotionally as well as communication skills. In other words, the word "education" comes from the Latin language. The meaning "taking out" or "drawing" is called to action of the value of man by changing his immature ability to developing his inner ability to maturity (Park, 2014). In this context, education can be seen as the whole of the development of the students. History is like a mirror of people's past. Thus, it can be said that history lessons have the ability to solve the problems by connecting the students with past, present and future and contributing to the development of their intelligence (Safran, 2011). Howard Gardner (as cited in Safran, 2011) researched about intelligence and he said, "For problem-solving capacity and problem solving, it is defined to have the ability to produce different solutions and the added value of collective-valued cultural products" (p. 55). In addition to this, the general purpose of history teaching today is not to

\footnotetext{
${ }^{1}$ MA Student at Sakarya University, History Education, Turkey, sevgicho@gmail.com

2 MA Student at Sakarya University, Psychological Services in Education, Turkey, hamlet.cho@gmail.com
} 
teach only history information but to acquire high level thinking skills to students. Hence, history teaching aims to develop historical thinking skills to students (Demircioğlu, 2010).

Safran (2011) mentioned in regards to meaning of historical thinking which is one of the elements that students should gain in this way, "Historical thinking, understanding history, making comments about the past and bridging the past and the present are the skills that students should develop" (p. 123). In high school history education, it is to awaken each student with a specific target and national emotions as well as it is necessary to aim at acquiring the historical thinking skills by moving away from the memorization of history with a certain strategy (Demircioğlu, 2010). Some studies have shown that students have negative attitudes about history (Safran, 2011). These students indicate that students are not interested in general history and are bored with it. "The reason for this situation is it has been shown that history lessons are taught based on memorization" (Safran, 2011, p. 56). In history lesson, instead of taking the course based on the transfer of historical information, using activities and experiences, developing historical thinking skills, creating curricula to solve different problems and social problems, and teaching with a student-centered approach are to be emphasized (Aslan, 2006). In addition, through the teaching of history, critical thinking skills must be given to the students (Safran, 2010). Critical thinking, problem solving, and creative thinking skills are considered to be top-level skills (Kaplan, 2014). In school, students should be taught how to think critically and use it regularly. The teaching of thinking needs to be prepared in a way as to direct students to think in the framework of teaching programs (Serefoğlu \& Akbıyık, 2006). However, students' thinking should be specific by making choices to have the ability to think critically (Seferoğlu \& Akbıyık, 2006). In England, the textbooks give great importance to critical thinking (Safran, 2011). It is necessary to be aware of any problems of students in modern society as well as it is necessary to provide a history education in a creative way by developing critical thinking skills to analyze (Şengül, 2009). Therefore, the curriculum should be of high quality.

It is known to be that in history teaching that the programs and practices have been studied in different countries. One of the researches is by Demircioğlu (2006) in his article, "A Comparative Evaluation of the General Purposes of Teaching History in the European Union Countries and Turkey" According to this article, when comparing the general aims of history teaching at the secondary level in the European Union countries (England, Holland, Austria, France) and Turkey, European countries predominantly emphasize in citizenship awareness, scientific thinking and high-level thinking skills, and the aims in Turkey emphasize the transfer of historical knowledge and culture.

There has been a study done by Ayşe Sarı, and her study was about the comparison of history programs of the high school education in Austria and Turkey. The study analyzed the similarities and differences between two countries high school programs, especially dealing with history programs (Sar1, 2007). Also, similar study was done to compare the history education in Armenia and Turkey, and it analyzed the similaries and differences of history education models of two countries and their textbooks. Similar to these studies, in this study, it is to compare the high school history education programs in terms of teaching-learning in South Korea and Turkey (Akpınar et al., 2017).

\section{Research Objectives}

Despite South Korea has suffered the Korean War (1950-1953), the success of economic development in South Korea in the last 50 years has been widely known. The economic success in South Korea has been mainly due to the improvement of educational system (Kim, 2002). The article in Word Education News 
\& Reviews in 2013 described the South Korea education in this way, "Based on international test scores, graduation rates and the prevalence of higher education seekers, South Korea is widely perceived as having one of the best K-12 education systems in the world" (Clark, 2013, p. 1). South Korean education has received praise from international leaders, especially from President Obama (Seth, 2016). Thus, South Korea is generally considered as a model of educational success to many politicians in the United States and other parts of the world (Owenby, 2015).

In respect to the success of South Korea education in recent years, this study is to see how Turkey education fares in comparison to South Korea education. Though Turkey education may not be widely known in the world in comparison to South Korea, this research is to find out the similarities and differences in education system of the two countries in the area of high school history teaching programs. In addition, it is see how history education programs have been influenced by contemporary approaches. Furthermore, is to find out what are similarities and differences of learning-teaching between high school history teaching programs in South Korea and Turkey. Whether one of the systems is more efficient or inefficient than the other system is open to discussion.

\section{METHOD}

The purpose of the research is to assess what the learning-teaching situation of high school history teaching programs in Korea and in Turkey is. This study was used with high school history curriculum document analysis technique in Korea and Turkey. Document analysis, which is a procedure for reviewing and evaluating documents, is quite important in qualitative research (Bowen, 2009). A descriptive method using qualitative measurement techniques has been adopted. "Qualitative research seeks to determine the meaning of a phenomenon through description. It aims to develop concepts that aid in the understanding of natural phenomena with emphasis on the meaning, experiences and views of the participants" (Al-Busaidi, 2008, p. 11). Unlike quanitative research, qualitative research does not use means of statistical procedures but it uses real settings that have occurred, and it doesn't seek to determine casual prediction, but it attempts to understand and show to similar events or circumstances (Golafshani, 2003). "While human emotions and perspectives from both subjects and researchers are considered undesirable biases confounding results in quantitative research, the same elements are considered essential and inevitable, if not treasurable, in qualitative research as they invariable add extra dimensions and colors to enrich the corpus of findings" (Leung, 2015, p. 324).

Concepts like reliability, validity, and generalisability are usually connected with quanitative research; however, qualitative research does not use these concepts (Noble \& Smith, 2015). Instead, qualitative research uses alternative criteria, such as truth value, consistency, and applicability. Truth value accepts that mutiple real situations are possible and the researchers' objective is to see the situations accurately without methodological bias. Consistency describes the methods that the researchers have used in a trustworthy way. Lastly, applicability explains that findings may be utilized in different situations, contexts, and people (Lincoln \& Guba, 1985).

In respect to methods done in this study, the researcher has taken account from all sides and unbiasedly has undertaken the study with accuracy. For example, the articles written in Korean language have been translated to English by the researcher along with other people who have expertise in KoreanEnglish language, and the articles written in Turkish language have been translated to English by the researcher along with other people who have expertise in Turkish-English language. To minimize the flaws and biases of translation, several translators have been used to review the translation which was done by the researcher. The study has been carefully undertaken with the consideration of the criteria of qualitative research. 
South Korea secondary history lesson programs were accessed via the internet and translated to English. Turkey secondary history lesson programs were accessed via the internet and translated to English. The comparisons between $9^{\text {th }}$ grade high school Korean history and Turkey 9th grade history course, between $10^{\text {th }}$ grade Korea East Asia history and Turkey 10th grade history course, and between $11^{\text {th }}$ grade Korea World history and $11^{\text {th }}$ grade Turkey Contemporary Turkish and World history course were made in respect to examining the similarities and differences of the learning-teaching situations of the history lesson programs between the two countries. "The scope and goal of teaching history in each country is determined by history teaching programs. As a creator of history, making programs is one of the most important aspects in educating people, and it is an extremely serious work. Considering the developments in the world and the information obtained as a result of new researches, these should always be kept alive and developed" (Sar1, 2007, p. 52). In this study, it is to examine the high school history education in terms of teaching-learning by comparing the secondary school history teaching programs between Korea and Turkey.

\section{FINDINGS}

This findings deal with how to learn as well as how to teach in high school setting. Similarities and differences in the case of learning-teaching situation between the two countries are shown.

Comparison of Learning-Teaching Situations in History Teaching Programs in South Korea and Turkey.

In the history program, the word of teaching-learning implies that it can be seen as a teaching or learning approach, depending on the perspective in which the interaction process is viewed. The choice of teaching methods and techniques appropriate to the target, subject, and situation undoubtedly enhances interest and draws effective participation. Student oriented makes classroom activities more effective and meaningful. As a general strategy, it is the application of a plan which is developed to achieve the path or to pursue purpose to achieve something. In this sense, strategy is a general approach that guides the determination of the methods, techniques and tools which enable to achieve the course objectives" (Sünbül, 2001, p. 1).

Both in Korea and Turkey, learning-teaching situations in the secondary education history programs are based on the historical foundation according to item 1, as shown in Table 1. The Turkey's section states, "Establishment of infrastructure for secondary history lesson and preparation of students levels (knowledge gained in primary education along with skills and values) as well as Primary Social Studies (grades 6-7) and Educational programs for Turkish Republic History of Revolution lessons should be examined." In the Korea's section, it states in this way, "To acquire historical knowledge of Korean history by understanding the basic trend of Korean history."

In addition, students are made to acquire historical thinking skills through history awareness. Item 4 of Table 1 in Turkey's section, item 2 of Table 1 in Korea History lesson (9 $9^{\text {th }}$ grade), item 1 of Table 2 in Korea's section, and item 3 and 8 in Table 3 in Korea's section show this information. Aim of the most of the developed countries is history lesson are to be acquired along with its skills to obtain the information (Demircioğlu, 2010). In the item 4 of Table 1 in Turkey's section, it states, "Lesson studies and activities in regards to historical thinking skills should be acquired and developed." In the item 1 of Table 2 in Korea's section, it states, "To provide a learning experience that is useful for improving the learner's ability to understand history and to improve the understanding of history." 
It is understood that by students actively participating in lesson, it enables students to make positive participation and motivate them. The item 7 of Table 1 in Turkey's section and the item 5 of Table 1 in Korea's section show this information. Historical sources, visual maps, and other materials are used in history lessons. This information is shown in the item 6 and 11 of Table 1 and the item 12 and 15 of Table 2 in Turkey's section. In Korea's section, the item 6 and 11 of Table 1, and the item 3 and 5 of Table 2, and the item 9 of Table 3 also show this information.

Concerning students using historical locations to learn and acquire historical imagination and creativity, the item 10 of Table 1 in Turkey's section and the item 8 of Table 1 in Korea's section show this information. In regards to students using visual tools in history lessons, the item 11 of Table 1 in Turkey's section and the item 4, 9, and 11 of Table 1 in Korea's section show this information. Concerning the historical context and its chronology in history lesson, the item 5 of Table 1 in Turkey's section and the item 7 of Table 2 in Korea's section show this information.

Some of the differences of learning-teaching in high school history programs are shown in the table, and of the differences is the critical thinking skill was much higher in Korea than in Turkey. The item 5 of Table 3 and the item 9 of Table 2 in Korea's section confirm this. According to the item 5 of Table 3 in Korea's section, it states, "It is important for the learners to reflect on the historical events so that they can reflect critically on the formation process of historical knowledge. It presents the possibility of a good interpretation."

There were more items of concerning using different methods and techniques teaching in history lessons in Korea than in Turkey. The item 9 of Table 1 in Turkey's section and the item 2, and 4, 11 of Table 2 in Korea's section show this information. Giving different kinds of teaching-learning and teaching with technology systems are different in Korea and in Turkey. The item 4 and 9 of Table 1 and the item 2, 4, 11 of Table 2, and the item 6 and 10 of Table 3 in Korea's section show this information. The item 9 of Table 1 in Turkey's section shows this information. Moreover, in Turkey, item 8 of Table 1 and 2 and item 7 of Table 3 emphasize the contribution of women and men in history of human. Likewise, in Korea, the expanded history of thinking is shown as to be different.

Learning-teaching situations between two countries are similar in content. The item 6 of Table 2 in Turkey's section, it states, “To process certain subjects in an integrated manner, appropriate to the contents of knowledge should be selected (administration, law, constitution, democracy, army, family, education, maritime, art, architecture, natural disasters, epidemics, migration, etc.), and it should be given to students as a project." In the Korea's section, the item 6 of Table 2 states, "Systematic explanations of content elements, examples, questions, learner's practice, self-examination, and evaluation process are related and taught." 


\section{Comparison of Learning-Teaching in High School History Programs in South Korea And Turkey: South Korea High School and Turkey High School (Grades 9-11)}

\section{Table 1.}

Comparison of Learning-Teaching Situations between Two Countries (9 ${ }^{\text {th }}$ grade)

\begin{tabular}{|c|c|}
\hline $\begin{array}{l}\text { History Course }\left(9^{\text {th }} \text { grade) Implementation of the }\right. \\
\text { Teaching Program Related Explanations } \\
\text { (Republic of Turkey Ministry of Education, 2007) }\end{array}$ & $\begin{array}{l}\text { Teaching-Learning Approach (9 } 9^{\text {th }} \text { grade) } \\
\text { (NCIC, 2015) }\end{array}$ \\
\hline $\begin{array}{l}\text { 1. Establishment of infrastructure for secondary } \\
\text { history lesson and preparation of students levels } \\
\text { (knowledge gained in primary education along with } \\
\text { skills and values) as well as Primary Social Studies } \\
\text { (grades 6-7) and Educational programs for Turkish } \\
\text { Republic History of Revolution lessons should be } \\
\text { examined. }\end{array}$ & $\begin{array}{l}\text { 1. To acquire historical knowledge of Korean } \\
\text { history by understanding the basic trend of Ko- } \\
\text { rean history. }\end{array}$ \\
\hline $\begin{array}{l}\text { 2. "History Science" unit is prepared as a key unit. } \\
\text { This unit is placed in relation to History of Method- } \\
\text { ologies. Students who have gained knowledge and } \\
\text { skills in this unit should be used in other units as } \\
\text { well. Thus, the knowledge and skills gained can be } \\
\text { internalized by the students. For example, a historic } \\
\text { event or different perspectives about objective ques- } \\
\text { tioning, evidence and data that have been presented } \\
\text { about the skill can be used in all history units. }\end{array}$ & $\begin{array}{l}\text { 2. To acquire the skills of historical thinking by } \\
\text { grasping the historical meaning and to be ap- } \\
\text { plied in today's life. }\end{array}$ \\
\hline $\begin{array}{l}\text { 3. The history of science should be emphasized in } \\
\text { relation to other sciences units. For example, in the } \\
\text { "The Birth of Civilization and the First Civilizations" } \\
\text { unit, the archeology and geography sciences should } \\
\text { be emphasized, and in the "History of the Civiliza- } \\
\text { tion of the Turkish States and its Civilization", pale- } \\
\text { ography and epigraphy sciences should be empha- } \\
\text { sized. }\end{array}$ & $\begin{array}{l}\text { 3. Students participate actively in class and teach } \\
\text { with different teaching styles. }\end{array}$ \\
\hline $\begin{array}{l}\text { 4. Lesson studies and activities in regards to histori- } \\
\text { cal thinking skills should be acquired and devel- } \\
\text { oped. }\end{array}$ & $\begin{array}{l}\text { 4. According to contents of learning, concept } \\
\text { learning, feed learning, subject learning, charac- } \\
\text { ter learning, inquiry learning, discussion learn- } \\
\text { ing, and information communication, it is to use } \\
\text { a variety of teaching and learning models such } \\
\text { as new technology-based learning, cooperative } \\
\text { learning, problem-based learning, and project }\end{array}$ \\
\hline
\end{tabular}




\begin{tabular}{|c|c|}
\hline & learning. \\
\hline $\begin{array}{l}\text { 5. Chronological thinking skills in respect to an } \\
\text { examination of the relationships between events or } \\
\text { historical reasons are important. With this under- } \\
\text { standing, the lesson that is gained while writing, the } \\
\text { chronology was noted. However, to be processed } \\
\text { some topics as integration in accordance with the } \\
\text { acquisition contents without chronological anxiety; } \\
\text { it is to select themes (scientific developments, feu- } \\
\text { dalism, slavery, democracy, human rights, religion, } \\
\text { army, family, education, maritime, natural disasters, } \\
\text { epidemics, migration etc.). These should be given to } \\
\text { students as a project. }\end{array}$ & $\begin{array}{l}\text { 5. For active participation of learners and induc- } \\
\text { ing internal motivation in history learning, it is } \\
\text { to use various teaching and learning models, } \\
\text { such as humane learning and project learning. } \\
\text { In addition, discussions, presentations, essays, } \\
\text { research, and other various participatory activi- } \\
\text { ties such as case studies are to be used. }\end{array}$ \\
\hline $\begin{array}{l}\text { 6. To provide simultaneous (synchronic) perception } \\
\text { of historical events to students, maps and other } \\
\text { materials should be used. Simultaneous history } \\
\text { strips should be prepared. }\end{array}$ & $\begin{array}{l}\text { 6. In addition to the basic data of historical re- } \\
\text { search, we also actively use visual materials such } \\
\text { as maps, chronology, pictures, charts and photo- } \\
\text { graphs to enhance a lively and fun class. }\end{array}$ \\
\hline $\begin{array}{l}\text { 7. It is very important to have the program table that } \\
\text { includes explanations, activities, and examples. } \\
\text { While preparing the course, general objectives, unit } \\
\text { knowledge and explanations should be taken con- } \\
\text { sideration. To provide active participation of the } \\
\text { students, to have effective and enjoyable lesson, } \\
\text { activities involving different methods and tech- } \\
\text { niques must be applied. When the activity is } \\
\text { planned, knowledge, descriptions, learning styles, } \\
\text { different types of student's intelligence, skills and } \\
\text { needs of the students and the environment in which } \\
\text { the school is located should be considered. }\end{array}$ & $\begin{array}{l}\text { 7. Learning by using literary works, TV dramas, } \\
\text { documentaries, and movies based on historical } \\
\text { events or characters, it fosters interest and makes } \\
\text { students to have motivation and positive partici- } \\
\text { pation. }\end{array}$ \\
\hline $\begin{array}{l}\text { 8. Achievements, integrated with political, social, } \\
\text { cultural and economic events should be taken into } \\
\text { account. In the formation of civilizations and cul- } \\
\text { tures, the contribution of woman and man and the } \\
\text { essence of history is "human" should be taken con- } \\
\text { sideration. }\end{array}$ & $\begin{array}{l}\text { 8. To develop historical imagination, creativity } \\
\text { and exploration, it is to use museums and histor- } \\
\text { ical sites to collect, preserve and display educa- } \\
\text { tional and cultural valuable artifacts and speci- } \\
\text { mens. Also, it cultivates the ability to appreciate } \\
\text { cultural assets. }\end{array}$ \\
\hline $\begin{array}{l}\text { 9. While program is applied, attendance to the } \\
\text { course and other courses should be taken considera- } \\
\text { tion and an effective communication should be }\end{array}$ & $\begin{array}{l}\text { 9. To cultivate the ability to process and utilize } \\
\text { the information required by the information } \\
\text { society, it is to use newspaper education, internet }\end{array}$ \\
\hline
\end{tabular}




\begin{tabular}{|l|l|}
\hline established with the teachers of the classes. & $\begin{array}{l}\text { education, film education, e-learning education, } \\
\text { and blended learning. }\end{array}$ \\
\hline $\begin{array}{l}\text { 10. The importance should be given to observation } \\
\text { visit trips and museums and historical places (His- } \\
\text { toric buildings, monuments, museum-cities, battle- } \\
\text { fields) should be arranged. }\end{array}$ & $\begin{array}{l}\text { 10. Rather than treating the contents of the text- } \\
\text { books with the same weight sequentially, it is } \\
\text { consider ways to adjust the order or combine } \\
\text { several topics to create a new one, or one topic in } \\
\text { depth. }\end{array}$ \\
\hline $\begin{array}{l}\text { 11. History courses should include visual communi- } \\
\text { cation tools, an overhead projector, a slide, and a } \\
\text { computer, a television etc. should be used as an } \\
\text { activity. Documents and films related to the } \\
\text { knowledge should be effectively used. }\end{array}$ & $\begin{array}{l}\text { 11. TV series, documentary, and film in history } \\
\text { lesson can be used in order to distinguish histor- } \\
\text { ary works. }\end{array}$ \\
\hline $\begin{array}{l}\text { 12. Book lists appropriate to the content of the unit } \\
\text { should be determined and these books should be } \\
\text { read. }\end{array}$ & \\
\hline
\end{tabular}

Table 2.

Comparison of Learning-Teaching Situations between Two Countries (10 ${ }^{\text {th }}$ grade)

\begin{tabular}{|c|c|}
\hline $\begin{array}{l}\text { History Course }\left(10^{\text {th }} \text { grade) Implementation of the }\right. \\
\text { Teaching Program Related Explanations } \\
\text { (Republic of Turkey Ministry of Education, 2008) }\end{array}$ & $\begin{array}{l}\text { Teaching-Learning Approach }\left(10^{\text {th }} \text { grade }\right) \\
\text { (NCIC, 2015) }\end{array}$ \\
\hline $\begin{array}{l}\text { 1. To provide chronological continuity and to de- } \\
\text { termine the readiness of the student. Class History } \\
\text { Course Curriculum should be examined. }\end{array}$ & $\begin{array}{l}\text { 1. To provide a learning experience that is useful } \\
\text { for improving the learner's ability to understand } \\
\text { history and to improve the understanding of } \\
\text { history. }\end{array}$ \\
\hline $\begin{array}{l}\text { 2. In } 9^{\text {th }} \text { Grade History Course Teaching Program } \\
\text { "History Science" unit, history methodology in } \\
\text { relation to knowledge should be discussed. The } \\
\text { knowledge and skills gained by the students in this } \\
\text { unit should also be used in 10th grade units. For } \\
\text { example, topics such as, Ankara War in the unit } 1 \\
\text { and the } 5^{\text {th }} \text { unit of the Tanzimat Ferman should be } \\
\text { paid to attention. }\end{array}$ & $\begin{array}{l}\text { 2. To prepare for the individual characteristics of } \\
\text { developing teaching and learning methods and } \\
\text { evaluation materials that are appropriate for } \\
\text { learners' learning ability and learning prepara- } \\
\text { tion. }\end{array}$ \\
\hline $\begin{array}{l}\text { 3. The history science to relation of other sciences } \\
\text { should be emphasized in units. For example, when } \\
\text { reasons and results of the Geographical discoveries }\end{array}$ & $\begin{array}{l}\text { 3. In order to enable learners to actively partici- } \\
\text { pate in teaching and learning situations, various } \\
\text { sources, graphics, statistics, multimedia re- }\end{array}$ \\
\hline
\end{tabular}


are examined in geography, the process of for-
mation of constitution should be used in legal dis-
ciplines.

4. Lesson work and activities should be directed to gain and develop historical thinking skills. sources are used.

4. With teaching purpose and content in mind, it is to use various teaching and learning methods, such as reading activity, club activity, on-thespot learning, theater learning, collaborative learning, decision-making learning, people learning, resources learning, cultural heritage learning, and project learning.

5. In order to meet the information society and increase the interest of the learners, it is to visit the Cyber museum, to utilize communication technology learning, internet use education, movie use education, and e-learning education. It is also to teach effectively of creative history by using computer.

6. Systematic explanations of content elements, examples, questions, learner's practice, selfexamination, and evaluation process are related and taught.

7. To understand important concepts and logical causal relationships, students should grasp the historical context rather than listing individual facts.

8. It is important to select important facts that students should know from past facts and events, and students are encouraged to establish their own historical concept by emphasizing the relationship so that they can develop ability to generalize.

9. In order to critically reflect on the formation process of historical knowledge, it is to show various possibilities of interpretation. 
While preparing the course, general objectives, unit knowledge and explanations should be taken consideration. To provide active participation of the learners and to have more effective and enjoyable lessons, activities involving different methods and techniques must be carried out. General Goals, achievements, explanations, learning styles, different types of intelligence students have, skills and needs of the students and the environment in which the school is located should be considered, and the new activities can be designed or suggested activities can be developed. While activities are being designed or developed, which stimulant, enhancer and evaluation processes should also be specified.

10. The concepts defined in the program and the historical terms are used in the relevant units (text, dictionary work etc. shape). Conceptual and historical terms of units are described below.

- Unit 1: The Fetret period, the dynasty, the reign, the custom, the feudal landlord, the voyvoda,

colonization, housing, health, occupation, trade guild, guild, mountain pass, religious worker, miriter, nomad,

composer

-Unit 2: Fetihname, Amanname, Babüssaade, Renaissance, Reform, Catholicism, Orthodoxy, Protestantism, Calvinism, inquisition, papacy, dogmatism, Humanism, harem, imperial council, rayah, pen, room, state, starboard, accident,

Muhtesip, domestics, quarry, one, enderun, holiday, ilmiye, kalemiye, fethiye, capitulation, treasure, complex

- Unit 3: Holy alliance, reform, parliament, legitimacy, absolutism, mercantilism, tax farmer, administrative center.

- Unit 4: Enlightenment, modernism, revolution, revolution, sublime porte, honorable people, senators, colonialism

- 5th Unit: Reforms, Panslavism, Panislamism,
10. By connecting issues such as East Asia to the educational curriculum, it is to recognize the solution of the problem of current history. 


\begin{tabular}{|c|c|}
\hline $\begin{array}{l}\text { Panturkism, Ottomanism, Westernism, Kanun-i } \\
\text { Esasi, Parliament-i Mebusan,sect, ationalism. }\end{array}$ & \\
\hline $\begin{array}{l}\text { 11. Care must be taken when linking the course } \\
\text { with other courses when the program is being ap- } \\
\text { plied. Effective communication should be estab- } \\
\text { lished with the teachers of the other courses. }\end{array}$ & $\begin{array}{l}\text { 11. In order to improve teaching and learning } \\
\text { methods, learners' satisfaction is confirmed in } \\
\text { various ways. }\end{array}$ \\
\hline $\begin{array}{l}\text { 12. To provide students with simultaneous (syn- } \\
\text { chronous) perception of historical events, materials, } \\
\text { such as maps should be used. } \\
\text { Concurrent history bands must be prepared and } \\
\text { historical atlases should be used. } \\
\text { Map studies, contemporary political maps, dumb, } \\
\text { nonverbal or rotated maps can be used. Concurrent } \\
\text { history bands Century, subject, space, person- } \\
\text { centered along with maps concurrent date strips } \\
\text { should be used. }\end{array}$ & \\
\hline $\begin{array}{l}\text { 13. The application of some methods and tech- } \\
\text { niques in the activity samples are need to be given } \\
\text { attention and the specifics are these: } \\
\text { - While activities including research method are } \\
\text { being carried out, a student should be given to } \\
\text { obtain resources via library, internet etc. if possible. } \\
\text { - In the activities proposed for writing text, skills of } \\
\text { historical thinking of students can be used to create } \\
\text { texts. Naming the period and correct use of histori- } \\
\text { cal terms and terms and time concepts should be } \\
\text { noted. However, students are not expected to write } \\
\text { texts like a historian. Guidance should be given to } \\
\text { students in regard to this. } \\
\text { - Text and visual materials (pictures, photographs, } \\
\text { cartoons, miniature, engraving, etc.) should be } \\
\text { appropriate to the student level and be pedagogic. } \\
\text { - For biographical activities, the biography of the } \\
\text { person studied, and ideas, activities and the effects } \\
\text { of the period of these activities should be addressed } \\
\text { in the political, social, cultural, economic features. } \\
\text { - In film activities, the course hours must be consid- } \\
\text { ered, and the content of the certain parts of the }\end{array}$ & \\
\hline
\end{tabular}




\begin{tabular}{|c|c|}
\hline appropriate film should be used in the events. & \\
\hline $\begin{array}{l}\text { 14. Attention should be paid to study visits during } \\
\text { lessons. Museum, historical and cultural locations } \\
\text { in the real or virtual environment (historical build- } \\
\text { ings, monuments, museums, and war zones) should } \\
\text { be organized. }\end{array}$ & \\
\hline $\begin{array}{l}\text { 15. Visual communication tools should be included } \\
\text { in history lessons. An overhead projector, slide, } \\
\text { computer, television etc. should be used in the } \\
\text { lesson effectively. The documentation of the } \\
\text { achievements, movies, etc. should be utilized. }\end{array}$ & \\
\hline $\begin{array}{l}\text { 16. One of the aims of history lesson is the correct, } \\
\text { effective and beautiful use of the Turkish language. } \\
\text { For this purpose, the appropriate content of a unit } \\
\text { of a story, novel, poem, etc., and lists that should be } \\
\text { determined, these books should be used in the } \\
\text { activities. }\end{array}$ & \\
\hline $\begin{array}{l}\text { 17. Accepted by the decision of the Board of Educa- } \\
\text { tion of the Republic of Turkey on } 14.06 .2002 \text { and } \\
\text { numbered } 272 \text {. Published in the Journal of the } \\
\text { Communiqués dated July } 2002 \text { and numbered } 2538 \\
\text { "Armenian, Greek Pontus And Syriacs "topics relat- } \\
\text { ed to the teaching of } 10 \text { classes of Secondary Histo- } \\
\text { ry teaching. } \\
\text { It is a must to take part in the program. The rele- } \\
\text { vant table is attached. }\end{array}$ & \\
\hline
\end{tabular}

Table 3.

Comparison of Learning-Teaching Situations between Two Countries (11 ${ }^{\text {th }}$ grade)

\begin{tabular}{|l|l|}
\hline $\begin{array}{l}\text { Contemporary Turkish and World History Course } \\
\text { Teaching Program Explanations Related to Applica- } \\
\text { tion }\left(11^{\text {th }} \text { grade) }\right.\end{array}$ & $\begin{array}{l}\text { Teaching-Learning Approach }\left(11^{\text {th }} \text { grade) }\right. \\
\text { (NCIC, 2015) }\end{array}$ \\
\hline $\begin{array}{l}\text { (Republic of Turkey Ministry of Education, 2008) } \\
\text { Science" unit, in relation to history methodology } \\
\text { achievements should be taken part in. The } \\
\text { knowledge and skills that students have gained in } \\
\text { this unit, Contemporary Turkish and World History }\end{array}$ & $\begin{array}{l}\text { 1. It is to be believed that world history is not } \\
\text { simply a thing that happened in the past, but that }\end{array}$ \\
\hline
\end{tabular}


lessons should also be provided. For example, in the 1st unit, Achievement Evaluation of the developments of the First World War and its aftermath" and "The treaties signed at the end of the war (including the Brest-Litowsk Agreement) is mentioned, and these treaties will be handled in terms of the victorious and defeated states."

Attention should be paid to the reflection of different aspects of the view.

2. The relation of history science in relation to other sciences should be emphasized in relevant units. For example, Unit 1 "Explains the emergence of the 1929 World Economic Crisis and its impact on the world." is applied, and the disciplines of economics, statistics and economics should be utilized.

3. It should be directed to lesson work and activities in order to gain and develop historical thinking skills.

3. Let the learner establish his / her own historical concept based on selecting important facts from past facts and events, highlighting the link between facts and events, and having the ability to generalize historical facts.

4. The order of the units is based on chronology. In the units, the contents of the achievements, date, name, and event are not to be ordered as such. When the unit content is determined, in relation to based on cause-effect, the chronological order, holistic perspective, and historical perception should be given to order. In this respect, the order of the knowledge should not be changed.

5. To process certain subjects in an integrated manner, appropriate to the contents of knowledge should be selected (administration, law, constitution, democracy, army, family, education, maritime, art, architecture, natural disasters, epidemics, migration, etc.), and it should be given to students as a project.

6. Knowledge: political, social, cultural and economic events together should be taken into account.

4. Provide learners with opportunities to learn various functions and cultivate values through learning world history.

5. It is important for the learners to reflect on the historical events so that they can reflect critically on the formation process of historical knowledge. It presents the possibility of a good interpretation.

6. Considering the learning goals and contents, the students will be able to use reading activities, club activities, and field experience learning, and learning methods such as decision making, character learning, feed learning, cultural learning, 


\begin{tabular}{|c|c|}
\hline & project learning, etc. \\
\hline $\begin{array}{l}\text { 7. In the formation of civilizations and cultures, the } \\
\text { contribution of a woman and a man and the essence } \\
\text { of history "human" should be noted. }\end{array}$ & $\begin{array}{l}\text { 7. The ability to solve problems is increased by } \\
\text { using various audiovisual materials related to } \\
\text { world history, and it also induces motivation and } \\
\text { interest of learners. }\end{array}$ \\
\hline $\begin{array}{l}\text { 8. The program chart where the examples of } \\
\text { achievement, explanation and activity are included } \\
\text { is very important. } \\
\text { While preparing the course, general objectives, unit } \\
\text { knowledge and explanations should be taken con- } \\
\text { sideration. To provide active participation of the } \\
\text { learners and to have more effective and enjoyable } \\
\text { lessons, activities involving different methods and } \\
\text { techniques must be carried out. General Goals, } \\
\text { achievements, explanations, learning styles, differ- } \\
\text { ent types of intelligence students have, skills and } \\
\text { needs of the students and the environment in which } \\
\text { the school is located should be considered, and the } \\
\text { new activities can be designed or suggested activi- } \\
\text { ties can be developed. While activities are being } \\
\text { designed or developed, which stimulant, enhancer } \\
\text { and evaluation processes should also be specified. }\end{array}$ & $\begin{array}{l}\text { 8. Section } 2-4 \text { expands students' historical per- } \\
\text { spectives by teaching and learning about the } \\
\text { history of the region and showing the relation- } \\
\text { ship between the regions and the relevant re- } \\
\text { sources. }\end{array}$ \\
\hline $\begin{array}{l}\text { 9. Effective communication with other teachers' } \\
\text { should be established. }\end{array}$ & $\begin{array}{l}\text { 9. In order to meet the information society and } \\
\text { increase the interest and interest of the learners, } \\
\text { use of communication technology, internet edu- } \\
\text { cation, movie education, and e-learning educa- } \\
\text { tion should be emphasized. We will actively } \\
\text { utilize historical learning that is based on creative } \\
\text { history teaching. }\end{array}$ \\
\hline $\begin{array}{l}\text { 10. To provide students with simultaneous (syn- } \\
\text { chronous) perception of historical events, materials, } \\
\text { such as maps should be used. } \\
\text { Concurrent history bands must be prepared and } \\
\text { historical atlases should be used. } \\
\text { Map studies, contemporary political maps, dumb, } \\
\text { nonverbal or rotated maps can be used. Concurrent } \\
\text { history bands Century, subject, space, person- } \\
\text { centered along with maps concurrent date strips } \\
\text { should be used. }\end{array}$ & $\begin{array}{l}\text { 10. To develop teaching-learning method, it is to } \\
\text { provide various methods that would satisfy } \\
\text { students. }\end{array}$ \\
\hline
\end{tabular}


11. The application of some methods and techniques in the activity samples are need to be given attention and the specifics are these:

- While activities including research method are being carried out, a student should be given to obtain resources via library, internet etc. if possible.

- In the activities proposed for writing text, skills of historical thinking of students can be used to create texts. Naming the period and correct use of historical terms and terms and time concepts should be noted. However, students are not expected to write texts like a historian. Guidance should be given to students in regard to this.

- Text and visual materials (pictures, photographs, cartoons, miniature, engraving, etc.) should be appropriate to the student level and be pedagogic.

- For biographical activities, the biography of the person studied, and education, activities and the effects of the period of these activities should be addressed in the political, social, cultural, economic features. In the biography work, the period of his / her ideas, arts, sports, music, literature and etc. should be included in the course of personalities.

- In film activities, the course hours must be considered, and the content of the certain parts of the appropriate film should be used in the events.

12. Attention should be paid to study visits during lessons. Museum, historical and cultural locations in the real or virtual environment (historical buildings, monuments, museums, and war zones) should be organized.

13. Visual communication tools should be included in history lessons. An overhead projector, a slide, a computer, a television etc. should be used in the lesson effectively. The documentation of the achievements, movies, etc. should be utilized.

14. One of the aims of history lesson is the correct, effective and beautiful use of the Turkish language. For this purpose, the appropriate content of a unit 
of a story, novel, poem, etc., and lists that should be

determined, these books should be used in the activities.

\section{DISCUSSION}

This study compares the learning-teaching experiences of high school history teaching programs in South Korea and Turkey and assesses the situation of the history teaching between the two countries. The comparison between Korea's history lesson and Turkey's high school history with the 9th grade history lesson in Turkey, between Korea's East Asian history lesson and the 10th grade history lesson in Turkey, between Korea's world history lesson and Contemporary Turkish history in $11^{\text {th }}$ grade has been made. This study attempts to find out the similarities and differences of Korea and Turkey's high school history lesson program by examining each learning-teaching article.

In the case of teaching-learning, both countries are seen to be built on historical bases. In addition, by using historical thinking skills and historical awareness, actively participating and motivating students, using historical resources and visual materials, using historical places, students are to enhance historical imagination and creativity. Concerning learning-teaching situations in secondary education history programs in Korea and Turkey, there are some differences in giving different kinds of teaching-learning lessons along with usage of technology systems. Another difference is that critical thinking was more applied in Korea than in Turkey. In secondary education in Turkey, the learning-teaching situations in the contemporary Turkish and world history programs emphasize that the history is the essence contribution of men and women. In secondary education in Korea, it is shown that critical thinking of the students were different.

The results of the study have shown that the two countries provide memorization based learning (MBL), and it is necessary to provide more useful applied systems instead of memorization based system. Memory based learning "has as its defining characteristic that it stores in memory all available instances of a task, and that it extrapolates from the most similar instances in memory to solve problems for which no solution is present in memory" (Daelemans \& Bosch, 2009, p. 3). Memory is important in any aspect of learning, because for a person to learn, he or she must remember and retain the information which it has been learned (Underwood, 2016). However, memory based learning has limitations in that it may undermine students understanding the materials in which they have learned and using critical thinking skills (Orlin, 2013). "The focus on memorization, fueled by standardized testing, has obstructed learning, according to Linda Darling-Hammond of Stanford University, who argues that students have been losing or squandering most of the information they acquire in school" (Tower, 2014). Like it has been discussed in this study, problem-solving skills of students, ability to interpret between past and present time, and critical thinking skills are necessary in history lesson. Instead of teaching students to memorize materials, it is necessary for students to develop thinking skills. Teachers have a big role to provide this skill to student.

A study which compared the history programs of the high school education in Austria and Turkey showed that there were similarities and differences. One of the similarities is that both countries help students use chronological orders to examine the relations between the great civilizations. Other similarity is that purpose of the history program of both countries is to transfer existing knowledge, to explore different sources and to provide research methods. (Sar1, 2007) One of the differences is that histo- 
ry lessons in Turkey's secondary education do not include political sciences; therefore, democratic behavior is not part of the aim. In contrary, the history of secondary education classes in Austria include political sciences, therefore, it is aimed to give democratic behavior to students.

Other study which compared the history programs of the high school education in Armenia and Turkey showed that there were similarities and differences. One of the similarities is that both countries lay out a chronological approach to history (Akpinar et al., 2017). One of the main differences in the study is that in Turkey's secondary history program, it emphasizes student-centered learning environments and encourages students to have ability of creative and critical thinking. However, in Armenia's secondary history program, it "remain largely ideological and center around patriotism and forming a national consciousness, leaving out many important aspects of studying history such as historical thinking and reasoning, critical thinking, exploring continuities and changes/discontinuities in history, and independent inquiry" (Akpinar et al., p. 48).

Both in Turkey and Korea, the recommendation is that history lessons should not be bored, and more resources are needed for better learning. In addition, it is suggested that visiting museum and historical sites, or having lessons outdoor can be useful for students to raise interest. In this study, in order for students to gain knowledge of history, it is suggested to visit ancient cities as an activity to provide education by seeing places where students can experience informally of historical events and discuss ideas about the topics they have seen. In order to develop the critical thinking skills of students, it is necessary to prepare the environments where the ideas can freely be shared between the teachers and the students and all kinds of problems can be discussed without hesitation. In order to determine the importance of teaching-learning within the curriculum in Turkey and Korea, I suggest that a study should be carried out by interviewing both students and teachers in Turkey and Korea and investigating the effective methods of learning-teaching history.

\section{REFERENCES}

Akpınar, A., Avetisyan, S., Balasanyan, H., Güllü, F., Kandolu, I., Karapetyan, M.,... Manasian, N. V. (2017). History education in schools in turkey and armenia a critique and alternatives. Istanbul and Yerevan:History Foundation (Tarih Vakfı) and Imagine Center for Conflict Transformation. Retrieved from http://caucasusedition.net/wp-content/uploads/2017/07/Tarih-Vakfi-andImagine-Final-Papers-June-20.pdf on 22. 06. 2017

Al-Busaidi, Z. Q. (2008). Qualitative research and its uses in health care. Sultan Qaboos University Medical Journal, $8, \quad 1, \quad 11-19 . \quad$ Retrived from https://www.ncbi.nlm.nih.gov/pmc/articles/PMC3087733/pdf/squmj-08-11.pdf on 16. 06. 2017

Aslan, E. (2006). Neden tarih öğretiyoruz? (Why we teach history?) Dokuz Eylül Üniversitesi Buca Eğtim Fakültesi Dergisi, 20, 162-174. Retrieved from http://web.deu.edu.tr/befdergi/19.pdf on 06. 01. 2016.

Atay, M. (2009). "Okullarda eğitimin amacı, yöntemi ve içeriğì". ("Purpose, method and content of education in schools"). Eğitim Hakkı ve Eğitimde Haklar Uluslararası İnsan Hakları Belgeleri Işığında Ulusal Mevzuatın Değerlendirilmesi. Retrieved from http://www.egitimdehaklar.org/pdf/2.pdf on 15. 12. 2015

Atay, M. (1996). A school for physically handicapped children in london and the importance of a computer in special education. Özel Eğitim Dergisi, 2, 44 - 55. Retrieved from http://dergiler.ankara.edu.tr/dergiler/39/45/381.pdf on 17. 12. 2015 
Bowen, G. A. (2009). Document analysis of a qualitative research method. Qualitative Research Journal, 9(2), 27- 40. Retrieved from http://dx.doi.org/10.3316/QRJ0902027 on 15. 06. 2017

Clark, N., \& Park, H. (2013, June 1). Education in South Korea. World Education News E Reviews. Retrived from http://wenr.wes.org/2013/06/wenr-june-2013-an-overview-of-education-in-southkorea on 18.06. 2017

Daelemans W., \& Bosch A. (2009). A draft chapter for the Blackwell computational linguistics and natural language processing handbook. Edited by Alex Clark, Chris Fox and Shalom Lappin. Retrived from http://www.clips.ua.ac.be/ walter/papers/2010/dv10.pdf on 20. 06. 2017

Demircioğlu, İ. H. (2010). Tarih öğretiminde ögrenci merkezli yaklaşımlar. (Student-Centered Approaches in History Teaching). Ankara: Anı Yayınc1l1k.

Demircioğlu, İ. H. (2006). A comparative evaluation of the general purposes of teaching history in the European Union Countries and Turkey). Frrat Üniversitesi Sosyal Bilimler Dergisi, 16, 133-146. Retrieved from http://web.firat.edu.tr/sosyalbil/dergi/arsiv/cilt16/sayi2/133-146.pdf on 11. 01. 2017

Golafshani, N. (2003). Understanding reliability and validity in qualitative research. The Qualitative Report, 8(4), 597-606. Retrieved from http://nsuworks.nova.edu/tqr/vol8/iss4/6 on 16. 06. 2017

Kaplan, A. S. (2014). Eleştirel düşünme becerileri okulu kitapçı̆̆ı. Retrieved from http://cocukuniversitesi.aydin.edu.tr/belgeler/elestirel.pdf on 16.04. 2016

Kim, Gwang-Jo. (2002). Education policies and reform in South Korea. Secondary Education in Africa: Strategies for Renewal, World Bank Africa Region. Ed. The World Bank, 29-40. Retrieved from https://pdfs.semanticscholar.org/d74b/8a82e7fb656b316c06d715b019e0cfc0fac7.pdf on 15. 06. 2017

Leung, L. (2015). Validity, reliability, and generalizability in qualitative research. Journal of Family Medicine and Primary Care, 4(3), 324-327. Retrieved from http://doi.org/10.4103/2249-4863.161306 on 15. 06. 2017

Lincoln, Y. S., \& Guba, E. G. (1985). Naturalistic inquiry. Beverly Hills, CA: Sage.

Milli Eğitim Bakanlığı (MEB). (2007). Ortaöğretim 9. sınıf tarih dersi programı. Ankara: Talim ve Terbiye Kurulu Başkanlığı Tarih Dersi Öğretim Programı Geliştirme Özel İhtisas Komisyonu. Retrieved from http://ogm.meb.gov.tr/belgeler/tarih9.pdf on 11. 12. 2015

Milli Eğitim Bakanlığı (MEB). (2008). Ortä̈ğretim 10. sınıf tarih dersi programı. Ankara: Talim ve Terbiye Kurulu Başkanlığı Tarih Dersi Öğretim Programı Geliştirme Özel İhtisas Komisyonu. Retrieved from http://etarih.com/tarih/mufredat/Programlar/tarih 10.pdf on 11. 12. 2015

Milli Eğitim Bakanlı̆̆ı (MEB). (2012). Ortä̈ğretim çağdaş türk ve dünya tarihi dersi öğretim programı. Ankara: Talim ve Terbiye Kurulu Başkanlığı Tarih Dersi Öğretim Programı Geliştirme Özel İhtisas Komisyonu. Retrieved from http://ogm.meb.gov.tr/belgeler/cagdas turkdunyatarih.pdf on 11. 12. 2015 
National Curriculum Information Center (NCIC). (2015). Education process in our country: High school education process (Volume 4) and social science education process (Volume 7). Retrieved from http://ncic.go.kr/mobile.kri.org4.inventoryTable.do;jsessionid on 11. 02. 2016

Noble H., \& Smith, J. (2015). Issues of validity and reliablility in qualitative research. Evidence-Based Nursing. Retrieved from http://dx.doi.org/10.1136/eb-2015-102054 on 16.06. 2017

Orlin, B. (2013, September 9). When memorization gets in the way of learning. The Atlantic. Retrieved from https://www.theatlantic.com/education/archive/2013/09/when-memorization-gets-in-

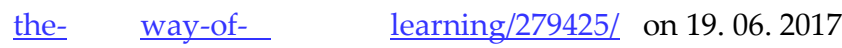

Owenby, T. (2015, May 8). What can the US learn from South Korea's educational system? World Economic Forum. Retrieved from https://www.weforum.org/agenda/2015/05/what-can-the-uslearn-from-south-koreas- education-system// on 21.06. 2017

Park, S. H. (2014. 4 Aralık). Education problems in the republic of Korea. Prezi Inc. Retrieved from https://prezi.com/sgyo45flkakw/presentation/ on 11.02. 2016

Safran, M. (2011). Tarihi nasıl öğretilir?: Tarih ögrretmenleri için özel ögretim yöntemleri. İstanbul: Yeni İnsan Yayın evi.

Sarı, A. (2007). Türkiye'deki (9, 10, 11, 12. Sınıf) ve Avusturya'daki (5,6,7,8. Sınıf) ortaögrretim tarih programlarının karşılaştırması. Ankara, Gazi University, Science Education Institute. 1-98.

Seferoğlu, S., \& Akbıyık C. (2006). Eleştirel düşünme ve öğretimi. Eğitim FakültesiDergisi (H.U. Journal of Education), 30, 193-200. Retrieved from http://yunus.hacettepe.edu.tr/ sadi/yayin/SeferogluAkbiyik_EFDergi-2006_Eles.Dusun.pdf on 11. 01. 2017.

Seth, M. (2016). South Korea's education exodus: The life and times of study abroad. Adrienne Lo et al. (Ed.). Journal of Korean Studies, 21(2), 527-531. Retrieved from https: //doi.org/10.1353/jks.2016.0024 on 17. 06. 2017

Sünbül, A. M. (2001, 6 Temmuz). Öğrenme-öğretme stratejisi.(Learning-teaching strategy). Retrieved from (http://ggurses2.tripod.com/ogretmenler1/ogretmenler15.htm on 9. 01. 2017

Şengül, T., \& Akça, N. (2009). Tarih öğretimi için yaratıcı ortamlar. Tarih Eğitimi Öğretimi Stratejileri Yöntemleri Forumda, 1-17. Retrieved from http://www.eab.org.tr/eab/2009/pdf/184.pdf on 15. 01. $\underline{2017}$ on 11. 12. 2016

Tower, L. (2014). Deeper learning: Moving students beyond memorization. NeaToday, Published on Nov. 25, 2014. Retrieved from http://neatoday.org/2014/11/25/deeper-learning-moving-studentsbeyond-memorization-2/ on 19.06. 2017

Underwood, B. J. (2016, January 29). Memory. Encyclopaedia Britannica. Encyclopaedia Britannica, Inc. Retrieved from https://www.britannica.com/topic/memory-psychology on 18. 06. 2017 